\title{
ЕНЕРГЕТИЧНА ЕФЕКТИВНІСТЬ ТЕРМООБРОБКИ РОСЛИННИХ МАТЕРІАЛІВ ЗА РІЗНИХ РЕЖИМІВ МІКРОХВИЛЬОВОГО ПРИСТРОЮ
}

\section{Колесниченко Н. О.}

\section{ВСТУП}

Завдяки особливостям взаємодії діелектричних матеріалів 3 мікрохвильовим (далі - MB) полем застосування мікрохвильової обробки в різних технологіях здатне привести до істотного поліпшення якості матеріалу. Виявлення особливих теплових і нетеплових ефектів мікрохвильової взаємодії 3 матеріалами пояснює широке коло досліджень, які відносяться до дослідження процесів сушки в мікрохвильовому полі ${ }^{1}$ процесів органічного синтезу ${ }^{2,3}$, процесів спікання технічної кераміки ${ }^{4,5}$ і металевих порошків ${ }^{6}$.

Обробка матеріалів рослинного походження має важливе значення для агропромислового комплексу. Зокрема, передпосівна обробка насіння застосовується для прискорення появи сходів, зниження захворюваності рослин. У результаті підвищується урожай. У традиційних технологіях насіння перед посівом прогрівають, калібрують, замочують у розчинах мікроелементів, дражируют i т. д. Процес

${ }^{1}$ Feng H., Yin Y., Tang J. Microwave drying of food and agricultural materials: basics and heat and mass transfer modeling. Food Engineering Reviews. 2012. Vol. 4, Issue 2. P. 89-106.

${ }^{2}$ Kappe C.O. Controlled microwave heating in modern organic synthesis. Angew. Chem. Int. Ed. Engl. 2004. Vol. 43. P. 6250-6284.

${ }^{3}$ Leonelli C.; Veronesi P. Chapter 2: Microwave Reactors for Chemical Synthesis and Biofuels Preparation In Production of Biofuels and Chemicals with Microwave // Biofuels and Biorefineries; Fang, Z., Smith, R.L., Jr., Qi, X., Eds.; Springer Science + Business Media: Dordrecht. The Netherlands. 2015. P. 17-40.

${ }^{4}$ Бурлуцкий Д.С., Калеева Ж.Г. Изменение физических свойств материалов в результате экспериментального воздействия шарового электрического разряда, полученного с помощью сверхвысокочастотного излучения. Современные наукоемкие технологии. 2011. № 5. С. 22-32.

5 Agrawal D. Microwave sintering of ceramics, composites and metal powders. Sintering of Advanced Materials Woodhead Publishing Series in Metals and Surface Engineering. 2010. P. 222-248.

${ }^{6}$ Srinath M.S., Apurbba Kumar Sharma, Pradeep Kumar. A new approach to joining of bulk copper using microwave energy. Materials and Design. 2011. Vol. 32. P. 2685-2694. 
передпосівної обробки тривалий, вимагає досить тривалої передпосівної обробки, великих матеріальних витрат і не завжди ефективний. Передпосівна обробка насіння в мікрохвильовому полі 3 метою біостимуляції порівняно 3 традиційними методами проста, енергетично ефективна, іiі тривалість становить декілька хвилин. Мікрохвильова біостимуляція насіння пов'язана 3 підвищенням транспортних властивостей рослинної тканини внаслідок розвитку високих градієнтів тиску в замкнутих мікрооб'ємах мікрофібрил клітинних стінок і пір ${ }^{7}$. Дія на клітинні стінки призводить до посилення транслокації поживних речовин і сприяє поліпшенню посівних якостей насіння. Ефективне використання об'ємного характеру мікрохвильового нагріву може бути отримане під час підготовки рослинного субстрату для дереворуйнівних грибів. Рослинний матеріал після МВ обробки не лише дезинфікується, але й покращує свої поживні властивості завдяки розривам целюлозних волокон ${ }^{8}$. На відміну від традиційних технологій пастеризації і стерилізації, процес MB підготовки субстрату значно скорочується по енерговитратах i тривалості.

Слід зазначити, що виявлені ефективність і унікальність мікрохвильового нагріву матеріалів в основному отримано на лабораторних установках. Перехід до практичного застосування 3 використанням промислових пристроїв вимагає рішення ряду взаємозв'язаних завдань, до яких відноситься вивчення особливостей мікрохвильової техніки, конструювання установки, перевірка іiі експлуатаційної ефективності під час обробки рослинного матеріалу. Представляється доцільним здійснювати перехід від лабораторних досліджень до промислового застосування з розробки установок малої потужності. Результати випробувань таких установок дозволяють просунутися в напрямі ефективного промислового застосування мікрохвильових технологій.

Одним із найбільш складних завдань $є$ забезпечення узгодження передавального тракту з масою завантажуваного матеріалу․․ Неповне поглинання мікрохвильової енергії оброблюваним матеріалом i відображення електромагнітних хвиль назад до магнетрона призводить до зниження ККД і відходу частоти від номінальної. 3 метою оцінки повноти використання мікрохвильової енергії та експлуатаційної

${ }^{7}$ Kalinin L.G., Boshkova I.L. Physical model of the response of the plant tissue to a microwave electromagnetic field. Biophysics. 2003. Vol. 48, № 1. P. 111-113.

8 Московский М.Н., Фридрих Р.А., Гуляев А.А. Структурный анализ поверхности соломы, обработанной СВЧ излучением. Вестник ДГТУ. 2010. Т. 10, № 5 (48). С. 648-654.

9 Сапунов Г.С. Ремонт микроволновых печей. М.: Солон. 1998. 268 с. 
ефективності застосування мікрохвильового пристрою потрібне проведення випробувань у різних режимах обробки рослинних матеріалів.

\section{1. Аналіз літературних даних і постановка проблеми}

$\mathrm{y}$ роботі $^{10}$ досліджено умови підвищення ефективності роботи установок термічної обробки сировини в разі впливу електромагнітного випромінювання. Досліджуються конструкції мікрохвильових камер, включаючи тороідальную. Автори відзначають, що в разі проектування тороідального резонатора для безперервної роботи необхідно зменшити еквівалентну ємність і збільшити еквівалентну індуктивність (тороідальную поверхню). У цьому випадку втрати мікрохвильової енергії зменшуються, i його ефективність зростає. Однак даний мікрохвильовий пристрій складний у виготовленні. Крім того, під час проектування геометричні характеристики узгоджувалися 3 довжиною хвилі мікрохвильового випромінювання у вакуумі. Однак у разі розташування матеріалу в резонансній камері довжина хвилі змінюється, й електромагнітне поле не буде відповідати тому, яке формується в порожній камері.

Автори роботи ${ }^{11}$ стверджують, що мікрохвильовій нагрів харчових продуктів є ефективним та економічно вигідним. Втрати поживних речовин під час приготування в мікрохвильовій печі не спостерігаються. Мікрохвильова обробка різних харчових продуктів також вивчалася авторами ${ }^{12}$. Відзначається, що мікрохвильовій нагрів для пастеризації та стерилізації сприяє ефективному знищенню патогенних мікроорганізмів і значно скорочує час обробки в порівнянні 3 традиційними методами. Однак автори відзначають, що у приготуванні харчових продуктів мікрохвильові технології поки поступаються традиційним щодо органолептичних характеристик. Таким чином, використання мікрохвильових пристроїв доцільно для обробки матеріалів, не призначених для безпосереднього вживання в їжу. Такими технологіями $\epsilon$ сушіння, дезінфекція, дезінсекції

${ }^{10}$ Increasing the Efficiency of the Operation of the Facilities for the Thermal Processing of Raw Materials by Exposure to Electromagnetic Radiation / Lukina D., Belov V., Lukina O., Volkov A., Mayorov A., Smirnova I. Key Engineering Materials. 2018. Vol. 781. P. 185-189.

${ }^{11}$ Okeke. C. Abioye A. E. Omosun Y. Microwave Heating Applications in Food Processing IOSR. Journal of Electrical and Electronics Engineering. Jul - Aug. 2014. Vol. 9, Issue 4 Ver. II . P. 29-34.

12 Potentials of Microwave Heating Technology for Select Food Processing Applications - a Brief Overview and Update / Puligundla P, Abdullah SA, Choi W, Jun S, Oh SE, et al. J Food Process Technol. 2013. Vol. 4, Issue 11. P. 1-9 
біостимуляції матеріалів рослинного походження. У роботі ${ }^{13}$ проведено порівняльну оцінку оптимальних режимних параметрів обробки рослинних матеріалів у технологіях біостимуляції насіння, стерилізації субстрату, сушки зерна. Результати отримані на експериментальній установці періодичної дії, тому значення таких характеристик, як темп нагріву і питомий тепловий потік, вимагають коректування для інших конструкцій.

$\mathrm{y}^{14}$ показано перспективність застосування мікрохвильової енергії для сушіння зернових. На підставі експериментальних даних встановлено, що мікрохвильове сушіння повинне супроводжуватися продувкою шару зерна. Тільки мікрохвильове конвективне сушіння забезпечує рівномірний нагрів і ефективне видалення вологи 3 шару. Мікрохвильовий пристрій для сушіння зерна має передбачати активне вентилювання.

У роботі $^{15}$ представлений огляд різних аспектів моделювання мікрохвильових пристроїв - від математичного формулювання до виділення необхідних функціональних вузлів.

Вивчення взаємозв'язку виду мікрохвильової камери, обсягу місткості продукції, діелектричних характеристик показує шляхи підвищення ефективності перетворення мікрохвильової енергії ${ }^{16}$. Тип мікрохвильової камери, тобто одномодова або багатомодова, а також конструкція і розмір камери безпосередньо впливають на ефективність мікрохвильового нагріву. Дослідники наголошують на необхідності узгодження мікрохвильової камери і навантаження для поліпшення концентрації енергії, у свою чергу ефективності нагріву. До недоліків роботи відноситься таке. Автори відзначають, що розвиток технології обробки на основі мікрохвильового випромінювання $€$ значним, оскільки воно зводить до мінімуму залежність від викопного палива й інших джерел енергії. Насправді отримання мікрохвильової енергії засновано на перетворенні електричної, яка у свою чергу отримана за

13 Study into effects of a microwave field on the plant tissue / N. Volgusheva, E. Altman, I. Boshkova A. Titlov, L. Boshkov // Eastern-European Journal of Enterprise Technologies. 2017. Vol. 6/8 (90). P. 47-54.

${ }^{14}$ Assessment of efficiency of drying grain materials using microwave heating / I. Boshkova, N. Volgusheva, A. Titlov, S. Titar, L. Boshkov. East-European Journal of Enterprise Technology: Energy-saving technologies and equipment. 2019. Vol. 1/8 (97). P. 78-86.

15 José C.Pedro, Telmo R.Cunha. Microwave De-embedding. From Theory to Applications. Chapter 7 - Behavioral Models for Microwave Circu-it Design Edited by: Giovanni Crupi and Dominique M.M.-P. Schreur. 2014. P. 255-315.

16 Praveen Kumar Loharkar, Asha Ingle, Suyog Jhavar. Parametric review of microwave-based materials processing and its applications. J. of matter Research and Technolgy. 2019. Vol. 8(3). P. 3306-3326. 
рахунок використання викопного палива, гідроенергетики, атомної енергії та ін. Тому питання енергетичної доцільності мікрохвильового нагріву в багатьох технологіях є визначальним. 3 цією метою вводиться поняття загального енергетичного ККД, яке враховує ККД мікрохвильової камери, ККД магнетрона i ККД електростанції. Узгодження магнетрона 3 мікрохвильовою камерою, в яку вміщено матеріал, дуже важливо. Погане узгодження призводить до зниження ККД і зсуву частоти генерації. Як показали дослідження ${ }^{17}$, відхилення тільки 5 МГц від номінальної частоти (2,45 ГГц) змінює поглинену водою мікрохвильову потужність приблизно на $20 \%$.

У статті $^{18}$ запропоновано нову багатокомпонентну конструкцію поворотного столу для поліпшення однорідності температури в мікрохвильових печах. Три обертові тарілки 3 поліетилену (PE) i глинозему, РЕ і алюмінію, а також глинозему й алюмінію, відповідно, використовуються в мікрохвильовій печі для моделювання. За порівняння 3 поворотними столами, що складаються 3 одного матеріалу, спостерігається збільшення рівномірності температури на 26-47\%. Однак для промислових пристроїв такий метод потребує подальшого вивчення.

\section{2. Матеріали та методи дослідження}

\section{1. Опис мікрохвильового пристрою для обробки сипучих матеріалів}

Мікрохвильові пристрої періодичної і безперервної дії в даний час випускаються спеціалізованими підприємствами, наприклад, компанією Linn High Therm GmbH (Німеччина). Однак установки не передбачені для обробки рослинних матеріалів. Їх застосування не за призначенням може призвести до локального перегріву i загоряння матеріалу. Компанія Ferrite Microwave Technologies (FMT) також виробляє мікрохвильові печі тунельного і камерного типу. Такі пристрої успішно можуть бути застосовані для розігріву порцій їжі на круїзних суднах або на літаках, однак для агропромислового комплексу їх застосування недоцільно. Крім того, запропоновані пристрої мають два недоліки. Для передачі енергії від генератора до матеріалу використовується хвилевід, виготовлення якого вимагає великих матеріальних витрат. Мікрохвильовий нагрів матеріалу відбувається в

17 Cherbański R., Rudniak L. Modelling of microwave heating of water in a monomode applicator - Influence of operating conditions. International Journal of Thermal Sciences. 2013. Vol. 74. P. 214-229.

${ }_{18}$ Model Stirrer Based on a Multi-Material Turntable for Microwave Processing Materials / Jinghua Ye, Tao Hong, Yuanyuan Wu, Li Wu, Yinhong Liao, et al. Materials (Basel). 2017. Vol. 10(2): 95. 
резонансної камері, що не забезпечує необхідну для задач, що розглядаються в даній роботі, рівномірність обробки. Мікрохвильові установки просипного типу для біостимуляції насіння пропонуються заводом Генератор (Україна, Київ). Незважаючи на проявлений біостимулюючий ефект, конструкція установки не дозволяс досить рівномірно обробляти насіння.

Для агропромислового комплексу актуальна оптимізація вартості мікрохвильового пристрою. Тому раціонально застосовувати рупорні антени для передачі енергії від магнетрона до рослинного матеріалу. Крім низької вартості виготовлення, рупорні антени дозволяють рівномірно опромінити матеріал. Розроблений у роботі мікрохвильовий пристрій призначений для обробки рослинних матеріалів у різних технологіях і передбачає застосування рупорних антен. У робочій камері передбачений продуктопровід, що знижує ризик загоряння матеріалу.

Схема мікрохвильового пристрою, розробленого і виготовленого для обробки сипучих матеріалів у різних технологіях, представлена на рис. 1 .

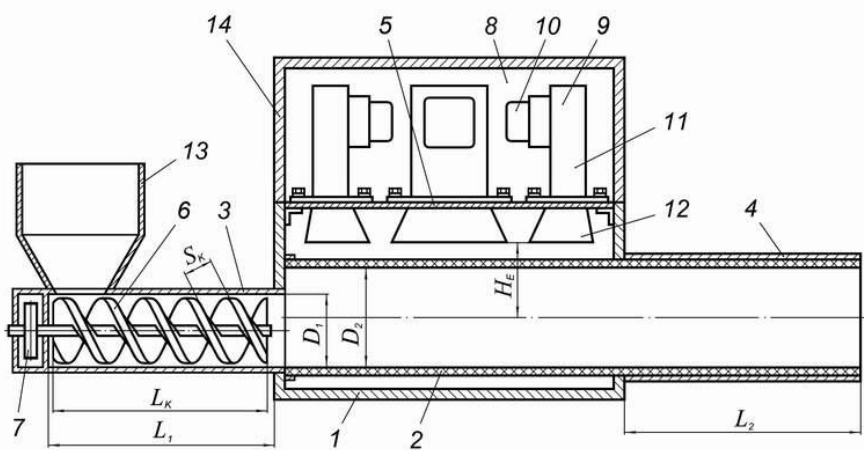

Рис. 1. Схема мікрохвильового пристрою безперервної дії для термообробки сипких матеріалів: 1 - робоча камера, 2 - продуктопровід, 3 - завантажувальний трубопровід, 4 - випускний трубопровід, 5 - перегородки, 6 - шнек, 7 - приводний вузол, 8 - технологічний відсік,

9 - мікрохвильові модулі, 10 - магнетрон, 11 - хвилевід, 12 - антенний випромінювач, 13 - завантажувальний бункер, 14 - кришка

Технічні характеристики установки такі.

Споживана потужність: 5 кВт; живлення: мережа однофазного струму, частота 50 Гц, напруга 220 вольт; потужність енергії в мікрохвильовій робочій камері: 3 кВт; частота СВЧ-поля в робочій камері: 2450 МГц; рекомендований робочий цикл: 50-хвилинна робота, 
19-хвилинна пауза; вид системи охолодження: примусова повітряна вентиляція.

Мікрохвильова установка містить робочу камеру, всередині якої розміщено продуктопровід. 3 паливопроводом з'єднаний завантажувальний i випускний трубопроводи для проходження оброблюваного продукту. Стінки камери, перегородки і трубопроводи виготовлені $з$ матеріалу, який не пропускає мікрохвилі. Внутрішній простір робочої камери виконано вологонепроникним від зовнішнього простору і від оброблюваного продукту. Продуктопровід виконаний у вигляді вологонепроникного трубопроводу i виготовлений 3 радіопрозорого матеріалу. У впускному трубопроводі розміщений шнек (гвинтовий конвеєр). Шнек установлений на консольному валу $\mathrm{i}$ 3'єднаний із приводним вузлом. У технологічному відсіку встановлені МВ модулі, які складаються 3 джерела МВ енергії (магнетрона), хвилеводу i антенного випромінювача. Технологічний відсік відокремлений від зовнішнього простору кришкою, яка виключає виток MB випромінювання з установки. Надлишки тепла, які утворюються в результаті роботи магнетронів і допоміжного обладнання, відводяться 3 технологічного відсіку через допоміжні вікна або жалюзі кришки (на малюнку умовно HE зображені). Довжина $\mathrm{L}_{1}$ впускного i $\mathrm{L}_{2}$ випускного трубопроводів виконана такою, щоб забезпечувати максимальне загасання електромагнітного опромінення до рівня, який є безпечним для обслуговуючого персоналу.

\section{2. Особливості роботи мікрохвильового пристрою для} термообробки сипких матеріалів

Принцип роботи установки заснований на поглинанні матеріалом, що підводиться в робочу камеру, мікрохвильової енергії. Матеріал рухається безперервним потоком у радіопрозорий канал, що проходить через робочу камеру. Роботу мікрохвильової установки можна представити таким чином. У завантажувальний бункер, розташований на зовнішньому кінці впускного трубопроводу, завантажується вихідний матеріал, яким може бути матеріал рослинного походження: насіння, зерно, деревна стружка і тирса, солома, лузга соняшника тощо. Приводний вузол обертає вал гвинтового конвеєра (шнека), який здійснює переміщення продукту від завантажувального бункера до продуктопроводу, і далі проштовхує через продуктопровід і випускний трубопровід назовні установки.

Під час проходження матеріалу в робочій камері здійснюється його опромінення МВ енергією. Магнетрон створює коливання ЕМП, і по хвилеводу вони передаються до антенного випромінювача, який направляє ЕМП на матеріал, який пересувається в радіопрозорий 
продуктопровід. Застосовується випромінювач рупорного типу. Рупорний випромінювач створює діаграму спрямованості електромагнітного поля, яка забезпечує рівномірне покриття поверхні продуктопроводу, без освіти тіньових зон. При цьому з метою запобігання небажаного розігріву шнека його довжина $\mathrm{L}_{\mathrm{K}}$ виконана такою, щоб кінець металевих частин, звернений до робочої камері, розташовувався поза зоною опромінення випромінювача.

На рис. 2 наведено фото установки, на рис. 3, 4 - окремі деталі установки.

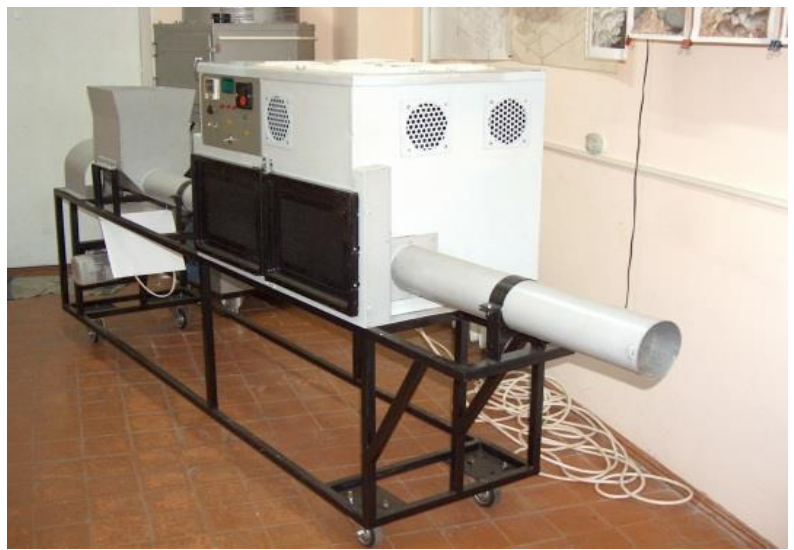

Рис. 2. Мікрохвильовий пристрій для термообробки сипких матеріалів

Система подачі оброблюваного матеріалу в установку включає шнек (рис. 3, б), що приводиться в дію за допомогою ланцюгової передачі (рис. 3, а) від електродвигуна.

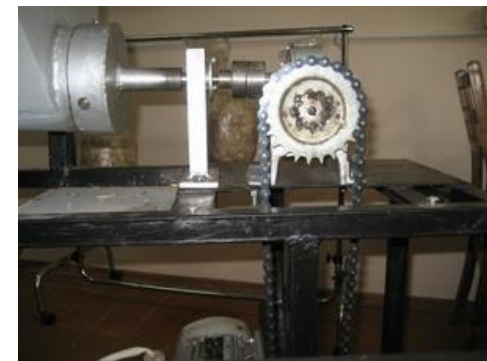

$a$

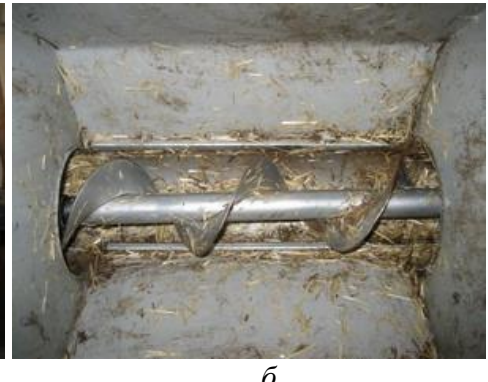

6

Рис. 3. Система подачі оброблюваного матеріалу в установку: a - приводний механізм; б - вид шнека в завантажувальному бункері установки 
Продуктопровід виконаний знімним для ефективного очищення після завершення робочого циклу. Технологічний відсік установки 3 мікрохвильовими модулями (рис. 4) ізольований від робочої камери 3 паливопроводом.
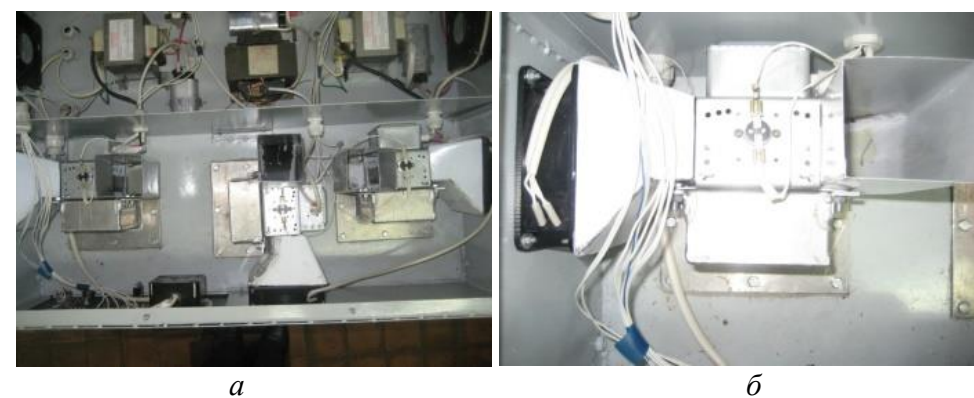

Рис. 4. Технологічний відсік установки з мікрохвильовими модулями: a - загальний вид зверху; $\boldsymbol{\sigma}$ - вид магнетрона $з$ повітроводами системи охолодження

Установка укомплектована трьома магнетронами, що серійно випускаються, 3 максимальною вихідною потужністю 1 кВт. Для забезпечення теплового режиму передбачена система повітряного охолодження. 3 цією метою виготовлені повітроводи, сумісні 3 технологічним відсіком установки (рис. 4,6 ).

Подача матеріалу за допомогою шнека підвищує компактність і покращує масогабаритні характеристики установки. Установка для термообробки сипких матеріалів була випробувана під час біостимуляції насіння пшениці й термообробки солом'яного субстрату.

\section{3. Методика мікрохвильової обробки субстрату із соломи для дереворуйнівних грибів}

Подрібнену солому замочують на 48 годин, після чого віджимають до вмісту вологи $\mathrm{W}=73 \%$. Вологий матеріал подається в установку $\mathrm{i}$ проходить по продуктопроводу, поглинаючи мікрохвильову енергію. У результаті температура матеріалу підвищується. Температура матеріалу в кінці обробки вимірюється мідь-константановими термопарами. Термопари розташовуються на поверхні шару соломи, в його центрі й на відстані 3 см від поверхні. Результати вимірювань усереднюються. Дія мікрохвильового поля здатна знищити шкідливу мікрофлору в оброблюваному грибному субстраті. Крім того, під дією мікрохвильової енергії відбувається часткове руйнування зовнішньої оболонки соломи, що в результаті прискорює процес заростання субстрату грибним міцелієм. 
Після обробки в мікрохвильовому пристрої солома охолоджувалася i інокулювала міцелієм. Потім інокулювану солому поміщали в поліетиленові пакети 3 прорізами для виходу плодових тел. Під час дослідження різних режимів обробки змінювалася витрата субстрату в діапазоні 5,5 • 10-3-9,0 • 10-3 кг/с.

\section{4. Методика оцінки впливу мікрохвильового поля на посівні якості насіння пшениці}

Проводилось дослідження ефекту біостимуляції пшениці. Зерно 3 витратою 0,83 • 10-2-2,1 • 10-2 кг/с через завантажувальний бункер надходило в робочий відсік, де опромінювалося мікрохвильовою енергією із заданою потужністю. 3 обробленого в МВ поле зерна відбирали дві аналітичні проби по 500 цілих зерен. Кожну пробу поміщали в скляну воронку, кінець якої був закритий гумовою трубкою iз затискачем. В отвір воронки поміщали скляну кульку. Воронка закріплювалася в тримачі штатива.

Зерно у воронці заливалося водою 3 температурою $20^{\circ \mathrm{C}}$ так, щоб рівень води був на 1,5-2,0 см вище поверхні зерна. Кожні 4 години вода 3 воронки зливалася, і зерно на 18 год. залишалося у воронці 3 відкритим затискачем. При цьому, щоб уникнути підсихання зерна, воронку накривали скляною кришкою 3 вологим фільтрувальним папером на внутрішній стороні. Потім затиск знову закривався, і зерно заливалося свіжою водою. Повторюючи таку процедуру, після 72 годин зерно розміщували на фільтрувальному папері й підраховували кількість зерен, які не проросли.

За отриманими даними розраховувалася енергія проростання:

$$
X_{1}=\frac{500-n_{1}}{500} \cdot 100 \% \text {, }
$$

де $\mathrm{n}_{1}$ - кількість не пророслого насіння.

Для визначення здатності проростання все насіння, включаючи не проросле, знову містилося у воронку, заливалися водою за відкритого затиску і витримувалися ще на 48 год. під скляною кришкою

Здатність проростання зерна кожної аналітичної проби у відсотках обчислюють за формулою:

$$
X_{2}=\frac{500-n_{2}}{500} \cdot 100 \% \text {, }
$$

де $\mathrm{n}_{2}$ - кількість зерен, які не проросли за 120 ч, шт.

За остаточний результат енергії і здатності проростання приймалося середнє арифметичне результатів визначень двох аналітичних проб. 


\section{3. Результати дослідження ефективності мікрохвильової обробки рослинного матеріалу}

\section{1. Термообробка солом'яного субстрату для дереворуйнівних грибів}

Випробування мікрохвильового пристрою в технології термообробки субстрату на початковому етапі призвело до встановлення граничного значення витрат і максимально допустимої швидкості руху матеріалу. Внаслідок подачі субстрату в завантажувальний бункер 3 витратою вище 9,2 • 10-2-9,5 • 10-2 кг/с спостерігалося забивання продуктопроводу, просування матеріалу гальмувалося. Швидкість руху матеріалу в продуктопроводі за витрати $\operatorname{Gmax}=9,2 \cdot 10-2$ кг/с відповідала 0,5 м/с. Це значення прийнято як максимально допустиме. Вплив термообробки в мікрохвильовому полі солом'яного субстрату було досліджено на дереворуйнівних грибах Глива (лат. Pleurotus). Глива росте швидко, що дозволяє в короткі терміни оцінити ефективність мікрохвильового методу приготування субстрату. Для їх вирощування формувалися субстратні блоки, інокульовані міцелієм. Вага кожного блоку становила 10 кг. На рис. 5 представлено фото гливи, що росте на субстратному блоці.

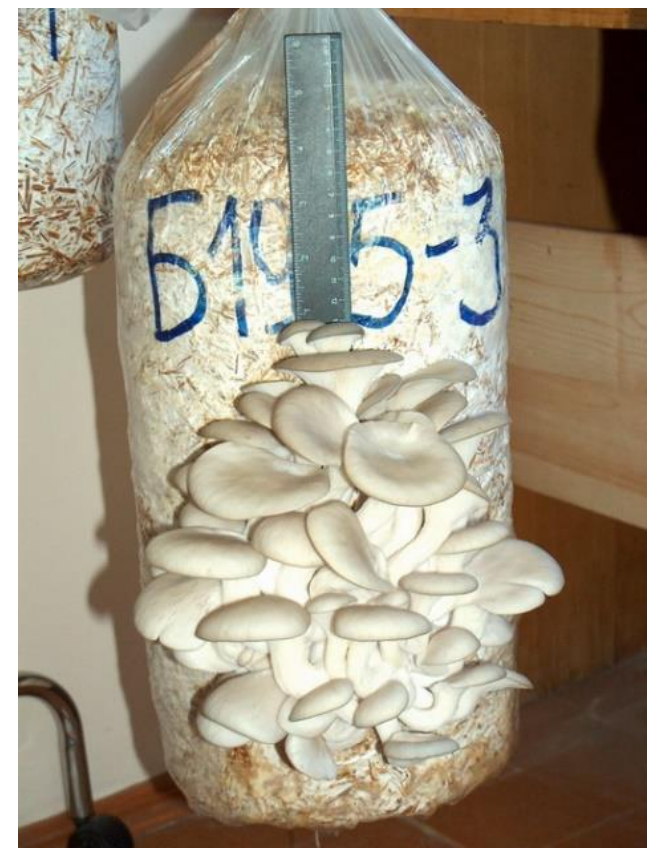

Рис. 5. Суббстратний блок із грибами Глива 
Щільність вологої соломи становила 400 кг/м3. Швидкість матеріалу в продуктопроводі у всіх дослідах була однакова і становила $\mathrm{w}=0,5 \mathrm{~m} /$ хв. Експозиція становила $\tau=180 \mathrm{c}$. Питомі витрати енергії визначалися як кількість теплоти Qm, Дж, віднесена до маси отриманої продукції після трьох хвиль плодоношення. Питома мікрохвильова потужність qv визначалася як відношення вихідної потужності трьох магнетронів до обсягу оброблюваного матеріалу в продуктопроводі.

Для оцінки енергетичної ефективності мікрохвильової обробки велике значення має ККД установки. Вираз загального ККД представляється в такому вигляді: $\eta=\eta_{m} \cdot \eta_{c}$, де $\eta_{m}-$ ККД магнетрона, $\eta_{c}$-ККД мікрохвиль камери. Значення $\eta_{m}$ показує, 3 яким ККД магнетрон перетворює енергію електричного поля промислової частоти (50 Гц) в енергію 3 частотою мікрохвильового поля. Ця величина $\epsilon$ паспортною і від умов обробки не залежить. Значення $\eta_{c}$ залежить від виду матеріалу, що завантажується, і його маси та визначається тепловими розрахунками. ККД камери показує, яка частина мікрохвильової енергії перетворена у внутрішню енергію оброблюваного матеріалу. У табл. 1 представлені дані, отримані після трьох хвиль плодоношення.

Таблиця 1

Кількість грибів, вирощених на субстраті після обробки в МВ полі. Початкова вологість $\mathrm{W}=\mathbf{7 3 \%}$

\begin{tabular}{|c|c|c|c|c|c|}
\hline № & $q_{v}, \mathrm{Bт} / \mathrm{M}^{3}$ & $\begin{array}{c}\text { Кінцева } \\
\text { температура, }{ }^{\circ} \mathrm{C}\end{array}$ & $\begin{array}{c}\text { Результат } \\
\text { (урожай 3 } \\
\text { блоку, кг) }\end{array}$ & $\begin{array}{c}Q_{m}, \\
\text { МДж/кг }\end{array}$ & $\eta_{c}, \%$ \\
\hline 1 & $7,24 \cdot 10^{5}$ & 72 & 2,35 & 0,38 & 48 \\
\hline 2 & $7,64 \cdot 10^{5}$ & 77 & 2,86 & 0,31 & 52 \\
\hline 3 & $8,12 \cdot 10^{5}$ & 92 & 3,64 & 0,25 & 60 \\
\hline 4 & $8,36 \cdot 10^{5}$ & 96 & 3,88 & 0,23 & 62 \\
\hline 5 & $8,68 \cdot 10^{5}$ & 96,5 & 3,90 & 0,23 & 59 \\
\hline 6 & $12,2 \cdot 10^{5}$ & 123 & 3,61 & 0,25 & 57 \\
\hline $\mathrm{CT}$ & - & 120 & 3,50 & 1,15 & - \\
\hline $\mathrm{K}$ & - & 20 & 0,350 & - & - \\
\hline
\end{tabular}

Режим СТ - обробка соломи в камері-стерилізаторі, 3 використанням традиційної технології згідно 3 режимами, встановленими для даної обробки (температура під час стерилізації сягає $120^{\circ \mathrm{C}}$, тиск $-1,5$ атмосфери). Тривалість стерилізації займає близько 3-х годин, що значно більше часу мікрохвильової обробки. 
Контроль К - режим, за якого термообробка не проводилася, солома замочувалася в гарячій воді й після віджимання інокулювалася міцелієм.

Оптимальним режимом можна вважати режим № 4, оскільки знятий практично максимально можливий урожай грибів, а питомі витрати енергії були мінімальні, досягався максимальний ККД камери.

ККД мікрохвильової камери розраховувався за рівнянням теплового балансу. Тепловий потік, що витрачаються на нагрів субстрату:

$$
Q=G \cdot c \cdot \Delta t,
$$

де $\mathrm{G}$ - витрата матеріалу, кг/с; с - теплоємність матеріалу, Дж / (кг • K), $\Delta \mathrm{t}$ - зміна температури, ${ }^{\circ} \mathrm{C}$.

ККД камери визначався як відношення поглиненого теплового потоку Q до вихідної потужності магнетрона. Втрати в навколишне середовище не враховувалися. Питома теплоємність вологої соломи визначалася відповідно до адитивної залежності ${ }^{19}$.

Дані табл. 1 показують, що збільшення температури до $96-96,5^{\circ} \mathrm{C}$ призводить до збільшення маси грибів, що, ймовірно, пов'язано 3 розпушеною целюлозою і збільшенням поживних якостей для гливи. Це припущення підтверджується дослідженнями. Автори роботи представили вид поверхні вихідних і оброблених в мікрохвильовому полі зразків соломи (рис. 6).

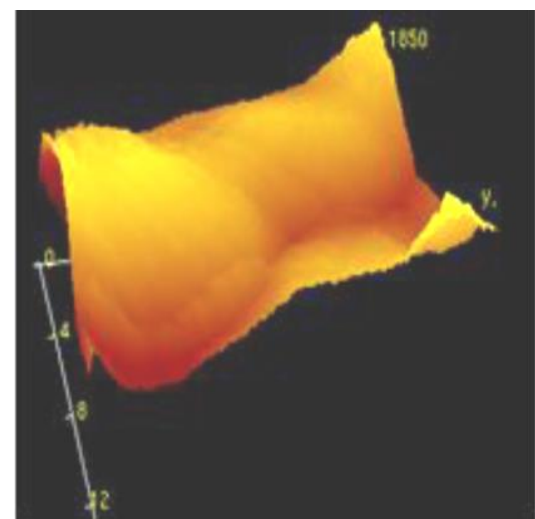

$a$

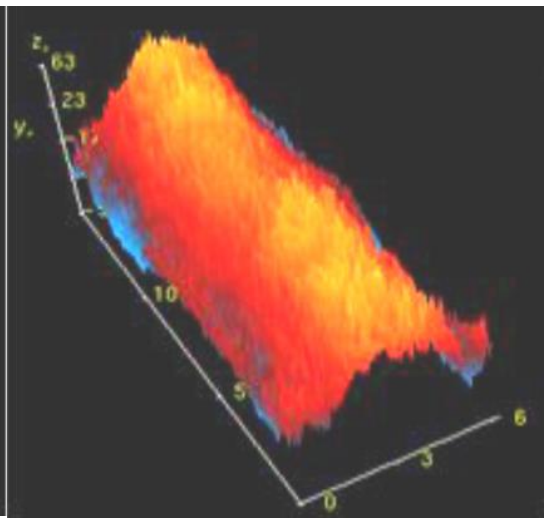

6

Рис. 6. Поверхня солом'яного матеріалу розміром 23 × 23 мкм: a - початкового; б - обробленого

19 Ефремова Е.Н., Карпачева Е.А. Хранение и переработка продукции растениеводства. Волгоград: ГАУ. 2015. 148 с. 
Поперечний зріз необробленої соломи характеризується гладкою поверхнею (рис. 6, а), а після мікрохвильової обробки спостерігається голчаста структура (рис. 6, б). Це явище пояснюється об'ємним характером нагрівання. Внаслідок мікровибухів усередині замкнутих обсягів у структурі матеріалу руйнуються волокна, i виникає неоднорідність. Такий матеріал набуває кращих поживних властивостей для зростаючих грибів.

\section{2. Вивчення впливу мікрохвильового поля на посівні якості насіння пшениці}

Дослідження проводилися на насінні пшениці сорту Одеська-162. Результати визначення лабораторної схожості та енергії проростання наведені в табл. 2. Швидкість руху шнека не змінювалася, вихідна потужність магнетронів регулювалася. Через особливості будови й принципу роботи магнетрона плавне регулювання потужності неможливе. Система управління включає і відключає магнетрон у процесі роботи, причому за кожного включення магнетрон працює на повну потужність. Під час роботи пристрою виставляється значення усередненої потужності, яка визначається тривалістю пауз і часом роботи магнетрона. Сумарна вихідна потужність магнетрона $\Sigma$ P ураховує вихідну потужність усіх працюючих магнетронів. Кінцева температура tf зерна визначалася за показниками трьох термопар, що розміщуються на різній відстані по його товщині. Початкова температура у всіх дослідах становила $19^{\circ} \mathrm{C}$. Питомі витрати енергії qm визначалися як відношення енергії, що витрачається до маси зерна, що одночасно перебуває в апараті.

Таблиця 2

Вплив мікрохвильової обробки на посівні якості насіння пшениці

\begin{tabular}{|c|c|c|c|c|c|c|}
\hline № & $\begin{array}{c}\Sigma P_{\text {out }}, \\
\text { кВт }\end{array}$ & $\begin{array}{c}\text { Витрата } \\
\text { зерна } G, \\
\text { ккг/с }\end{array}$ & $t_{f},{ }^{\circ} \mathrm{C}$ & $q_{m}, \mathrm{~B}$ т/кг & $\begin{array}{c}\text { Енергія } \\
\text { проростання }\end{array}$ & $\begin{array}{c}\text { Здатність } \\
\text { проростання }\end{array}$ \\
\hline 1 & 0,3 & $0,83 \cdot 10^{-5}$ & 27,0 & 201 & 82 & 86 \\
\hline 2 & 0,6 & $1,62 \cdot 10^{-5}$ & 27,3 & 205 & 84 & 88 \\
\hline 3 & 0,6 & $2,1 \cdot 10^{-5}$ & 25,3 & 158 & 84 & 89 \\
\hline 4 & 0,9 & $2,1 \cdot 10^{-5}$ & 28,5 & 238 & 83 & 87 \\
\hline 5 & 1,8 & $2,1 \cdot 10^{-5}$ & 38,0 & 476 & 72 & 78 \\
\hline $\mathrm{K}$ & - & - & - & - & 78 & 83 \\
\hline
\end{tabular}

Дані табл. 2 свідчать, що підвищення температури має свою межу, за яким ефект біостимуляції починає знижуватися. Це пов'язано 3 перегрівом зародків насіння, вміст вологи яких вище середнього за 
обсягом зернової маси. На рис. 7 наведені фотографії кореневої системи i паростків пшениці, насіння якої зазнали обробці в мікрохвильовому полі.

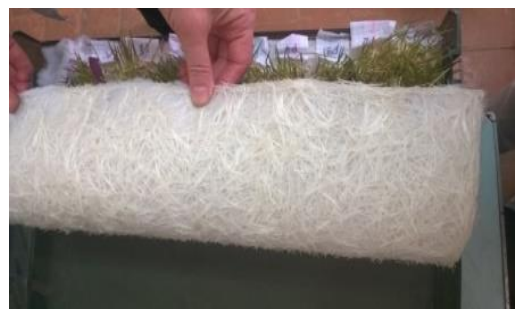

$a$

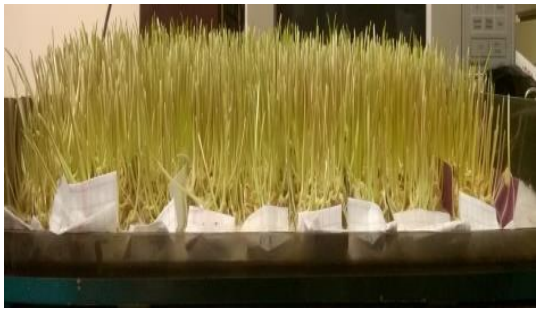

6

Рис. 7. Результати пророщування насіння пшениці після обробки: а - вид кореневої системи, б - вид пророслої пшениці

Результати свідчать, що після обробки всі рослини проявляють біостимулюючий ефект мікрохвильового поля. У зазначеному діапазоні питомих витрат енергії qm особливих відмінностей в інтенсивності росту не спостерігалося. Контрольний варіант (насіння без обробки) проростав менш інтенсивно, на рис. 7б - паростки крайні справа.

\section{4. Обговорення результатів обробки рослинних матеріалів} у розробленому мікрохвильовому пристрої

Мікрохвильові технології показують свою перспективність, однак режими обробки повинні відпрацьовуватися на кожній конструкції мікрохвильового пристрою. Випробування мікрохвильового пристрою під час термообробки субстрату показало, що перевищення витрат вище максимально допустимого значення $G_{\max }=9,2 \cdot 10^{-2}$ кг/с призводить до забивання продуктопроводу, просування матеріалу гальмується. Швидкість руху матеріалу в продуктопроводі за витрати $9,2 \cdot 10^{-2}$ кг/с відповідала $0,5 \mathrm{~m} / \mathrm{xв}$ i визначена як максимально допустима. Збільшення швидкості й витрати оброблюваного матеріалу можна забезпечити в разі застосування шнека, що проходить по всій довжині продуктопроводу. При цьому шнек слід виготовляти у вигляді складеної конструкції. Шнек у продуктопроводі повинен бути 3 радіопрозорого полімеру, а шнек у завантажувальному бункері бажано виготовляти металевим для забезпечення міцності і зносостійкості механізмів, що подають. Проведені теплові розрахунки для оцінки коефіцієнта корисної дії мікрохвильової камери демонструють істотну залежність ККД від питомої мікрохвильової потужності. У разі зміни питомої потужності в межах $15 \%$ в діапазоні від $7,24 \cdot 10^{5} \mathrm{BT} / \mathrm{m}^{3}$ 
до 8,36 • 105 Вт/м3 ККД збільшився на 29\%. Пройшовши максимальне значення, ККД дещо знижується. Причину цього явища слід шукати в зменшенні області опромінення матеріалу за зменшення витрат. В оптимальному режимі значення ККД відповідало 62\% (№ 4 табл. 1). Надалі слід розглянути шляхи збільшення ККД.

Результати випробування мікрохвильової обробки показують, що вона ефективніше традиційної стерилізації (табл. 1). Витрати енергії в оптимальному режимі мікрохвильової обробки - в п'ять разів менше, крім того, тривалість обробки для невеликих обсягів істотно нижче, оскільки стерилізація передбачає витримку протягом трьох годин. Аналіз даних табл. 1 показує, що збільшення температури матеріалу на виході до 96-96,5 ${ }^{\circ} \mathrm{C}$ призводить до поліпшення поживних якостей субстрату, про що свідчить отриманий урожай гливи. Процес термообробки субстрату в мікрохвильовому пристрої енергетично більш вигідний у порівнянні з традиційною стерилізацією і дозволяє отримати більший урожай грибів. Тривалість стерилізації займає близько 3-х годин, що значно більше часу мікрохвильової обробки. Крім того, мікрохвильова технологія підготовки субстрату не потребує підтримки підвищеного тиску, що передбачено в стерилізаторі. Відсутність цвілевих грибів на субстраті свідчить про рівномірність обробки (рис. 5).

Представлений мікрохвильовий пристрій можна успішно використовувати для передпосівної обробки насіння. Мікрохвильова обробка насіння озимої пшениці Одеська-162 протягом 180 с при зміні мікрохвильової потужності в межах $0,3-0,9$ кВт привела до збільшення енергії проростання та лабораторної схожості (табл. 2). Вид паростків 3 обробленого насіння практично не залежав від режиму обробки в заданому діапазоні (рис. 7, б). Отже, деякі відхилення від оптимального режиму не приведуть до значних змін у проявах ефекту біостимуляції. Для отримання режимів обробки насіння інших видів необхідні додаткові дослідження.

Обмеженнями дослідження $є$ те, що були вибрані тільки два види рослинних матеріалів. Водночас фермерські господарства можуть мати інтерес в биостимуляції різних видів насіння, що також вимагає встановлення оптимальних режимів. Також термообробка солом'яного субстрату не дозволяє перенести результати на субстрати 3 інших рослинних наповнювачів. Для запобігання перегріву трансформаторів необхідні паузи в роботі, що знижує іiї продуктивність. До недоліків мікрохвильової обробки сипучих матеріалів на випробуваній установці відноситься те, що обсяги матеріалу невеликі. Так, у разі підготовки субстрату можливо отримання 200 кг у день, тобто одна установка може забезпечити 20 блоків. За передпосівної підготовки насіння 
пшениці можна обробити 460 кг. Така продуктивність буде представляти інтерес для невеликих господарств.

Тестування розробленого пристрою в різних режимах обробки вирішує проблему переходу до практичного застосування мікрохвильових технологій. Розроблений мікрохвильовий пристрій безперервної дії може бути застосований у встановлених оптимальних режимах для термообробки сипких матеріалів у технологіях біостимуляції і підготовки субстрату для дереворуйнівних грибів. Надалі доцільно випробувати мікрохвильовий пристрій на стерилізації комбікормів. У такому випадку розроблений пристрій може отримати більш широке застосування.

\section{ВИСНОВКИ}

Дослідження роботи мікрохвильової установки для обробки сипучих матеріалів показали, що для даної конструкції існує гранична швидкість подачі матеріалу в робочу камеру. Для стабільного i рівномірного просування матеріалу слід підтримувати швидкість руху не вище 0,5 м/хв. Завдяки узгодженню довжини хвилі мікрохвильового випромінювання з геометричними характеристиками продуктопроводу ККД мікрохвильової камери сягає 62\%. Розроблена мікрохвильова установка безперервної дії може бути рекомендована до застосування в спеціалізованих фермерських господарствах.

Вивчення впливу мікрохвильової обробки на якість солом'яного субстрату показало, що отриманий субстрат є кондиційним і сприяє інтенсивному росту дереворуйнівних грибів Глива. Мікрохвильова підготовка субстрату вимагає значно менших витрат енергії в порівнянні з традиційними технологіями. Так, якщо для традиційної стерилізації питомі витрати енергії становлять $\mathrm{Qm}=1,15$ МДж/кг, в оптимальному режимі мікрохвильової обробки питомі витрати дорівнювали $\mathrm{Qm}=0,23$ МДж/кг. При цьому урожай грибів гливи збільшився на $11 \%$, що пов'язано 3 поліпшенням поживних властивостей солом'яного субстрату.

Дослідження ефекту біостимуляції насіння в мікрохвильовій установці показали, що мікрохвильова обробка призводить до збільшення енергії схожості і здатності проростання в діапазоні потужності, що підводиться 0,3-0,9 кВт за тривалості обробки 180 с. У порівнянні з контролем (необроблені насіння), енергія проростання збільшилася на 8\%, здатність проростання - на 7,4\%. Для застосування представленої установки з метою біостимуляції необхідно регулювати вихідну потужність кожного магнетрона. У разі підвищення кінцевої температури до $38{ }^{\circ} \mathrm{C}$ ефект біостимуляції знижується, і відзначається погіршення посівних якостей. В оптимальному режимі питомі витрати енергії 158 Вт/кг, тривалість обробки - 180 с, середня кінцева температура насіння $-28,5^{\circ} \mathrm{C}$. 


\section{АНОТАЦІЯ}

Проведено випробування мікрохвильового пристрою безперервної дії для термообробки рослинних матеріалів, яке розроблено та сконструйовано для реалізації мікрохвильових технологій у промисловості. Метою випробувань була оцінка ефективності мікрохвильового пристрою за показниками якості отриманого матеріалу й енергетичних витрат, зумовленими ефективністю перетворення мікрохвильової енергії у внутрішню енергію матеріалу. Проведено дослідження впливу мікрохвильової обробки солом'яного субстрату для дереворуйнівних грибів. Якість обробки визначалася по врожайності грибів Глива (Pleurotus), вирощених на отриманому субстраті. Мікрохвильова обробка проведена на різних режимах, які відрізнялися значенням питомої потужності. Під час аналізу ефективності мікрохвильової обробки проводилося зіставлення результатів 3 даними, що отримуються за традиційної технології стерилізації соломи. Показано, що врожай грибів гливи збільшився на $11 \%$. Отримано, що в оптимальному режимі питома потужність становила $\mathrm{q}_{\mathrm{v}}=8,68 \cdot 10^{5} \mathrm{BT} / \mathrm{M}^{3}$, кінцева температура $\mathrm{t}=96^{\circ} \mathrm{C}$, тривалість обробки - 180 с. За тепловими розрахунками визначені значення ККД мікрохвильової камери $\eta_{c}$, в оптимальному режимі $\eta_{\mathrm{c}}=62 \%$. Досліджено вплив мікрохвильової обробки на посівні характеристики насіннєвого зерна пшениці. Ефективність мікрохвильової обробки визначалася за значеннями лабораторної схожості та енергії проростання насіння. В оптимальному режимі вихідна потужність магнетронів становила $\Sigma \mathrm{P}_{\text {out }}=0,6 \mathrm{\kappa B}$, витрата зерна $\mathrm{G}=2,1 \cdot 10^{-2} \mathrm{\kappa} / \mathrm{c}$. Дослідження роботи мікрохвильової установки довело, що для даної конструкції для стабільного і рівномірного просування матеріалу по продуктопроводу слід підтримувати швидкість руху не вище 0,5 м/хв. Рекомендується застосовувати випробувану мікрохвильову установку безперервної дії в спеціалізованих фермерських господарствах.

\section{ЛITЕРАТУРА}

1. Feng H., Yin Y., Tang J. Microwave drying of food and agricultural materials: basics and heat and mass transfer modeling. Food Engineering Reviews. 2012. Vol. 4. Issue 2. P. 89-106.

2. Kappe C.O. Controlled microwave heating in modern organic synthesis. Angew. Chem. Int. Ed. Engl. 2004. Vol. 43. P. 6250-6284.

3. Leonelli C., Veronesi P. Chapter 2: Microwave Reactors for Chemical Synthesis and Biofuels Preparation In Production of Biofuels and Chemicals with Microwave. Biofuels and Biorefineries ; Fang, Z., Smith, R.L., Jr., Qi, X., Eds. ; Springer Science + Business Media : Dordrecht. The Netherlands, 2015. P. 17-40. 
4. Бурлуцкий Д.С., Калеева Ж.Г. Изменение физических свойств материалов в результате экспериментального воздействия шарового электрического разряда, полученного с помощью сверхвысокочастотного излучения. Современные наукоемкие технологии. 2011. № 5 . С. 22-32.

5. Agrawal D. Microwave sintering of ceramics, composites and metal powders. Sintering of Advanced Materials Woodhead Publishing Series in Metals and Surface Engineering. 2010. P. 222-248.

6. Srinath M.S., Apurbba Kumar Sharma, Pradeep Kumar. A new approach to joining of bulk copper using microwave energy. Materials and Design. 2011. Vol. 32. P. 2685-2694.

7. Kalinin L.G., Boshkova I.L. Physical model of the response of the plant tissue to a microwave electromagnetic field. Biophysics. 2003. Vol. 48. № 1. P. 111-113.

8. Московский М.Н., Фридрих Р.А., Гуляев А.А. Структурный анализ поверхности соломы, обработанной СВЧ излучением. Вестн. ДГТУ. 2010. Т. 10. № 5 (48). С. 648-654.

9. Сапунов Г.С. Ремонт микроволновых печей. Москва : Солон, 1998. $268 \mathrm{c}$.

10. Increasing the Efficiency of the Operation of the Facilities for the Thermal Processing of Raw Materials by Exposure to Electromagnetic Radiation / D. Lukina D. at al. Key Engineering Materials. 2018. Vol. 781. P. 185-189.

11. Okeke C., Abioye A.E., Omosun Y. Microwave Heating Applications in Food ProcessingIOSR. Journal of Electrical and Electronics Engineering. 2014. Jul - Aug. Vol. 9. Issue 4. Ver. II. P. 29-34.

12. Potentials of Microwave Heating Technology for Select Food Processing Applications - a Brief Overview and Update / P. Puligundla et al. J Food Process Technol. 2013. Vol. 4. Issue 11. P. 1-9.

13. Study into effects of a microwave field on the plant tissue / N. Volgusheva at al. Eastern-European Journal of Enterprise Technologies. 2017. Vol. 6/8 (90). P. 47-54.

14. Assessment of efficiency of drying grain materials using microwave heating / I. Boshkova at al. East-European Journal of Enterprise Technology: Energy-saving technologies and equipment. 2019. Vol. 1/8 (97). P. 78-86.

15. José C.Pedro, Telmo R.Cunha. Microwave De-embedding. From Theory to Applications. Chapter 7 - Behavioral Models for Microwave Circu-it Design : Edited by : Giovanni Crupi and Dominique M.M.-P. Schreur. 2014. P. 255-315. 
16. Praveen Kumar Loharkar, Asha Ingle, Suyog Jhavar. Parametric review of microwave-based materials processing and its applications. $J$. of matter Research and Technolgy. 2019. Vol. 8 (3). P. 3306-3326.

17. Cherbański R., Rudniak L. Modelling of microwave heating of water in a monomode applicator - Influence of operating conditions. International Journal of Thermal Sciences. 2013. Vol. 74. P. 214-229.

18. Model Stirrer Based on a Multi-Material Turntable for Microwave Processing Materials / Jinghua Ye et al. Materials (Basel). 2017. Vol. 10 (2). 95.

19. Ефремова Е.Н., Карпачева Е.А. Хранение и переработка продукции растениеводства. Волгоград : ГАУ, 2015. 148 с.

Information about the author:

Kolesnychenko N. O.,

Candidate of Technical Sciences, Associate Professor of the Department of Technical Support of the Odessa Military Academy 10, Fontanskaya road, Odesa, 65000, Ukraine 